Utah State University

DigitalCommons@USU

Co

Bee Lab

6-14-1910

\title{
The North American Bees of the Genus Nomia
}

T. D. A. Cockerell

University of Colorado

Follow this and additional works at: https://digitalcommons.usu.edu/bee_lab_co

Part of the Entomology Commons

\section{Recommended Citation}

Cockerell, T. D. A., "The North American Bees of the Genus Nomia" (1910). Co. Paper 265.

https://digitalcommons.usu.edu/bee_lab_co/265

This Article is brought to you for free and open access by the Bee Lab at DigitalCommons@USU. It has been

accepted for inclusion in Co by an authorized administrator of DigitalCommons@USU. For more information, please contact digitalcommons@usu.edu.

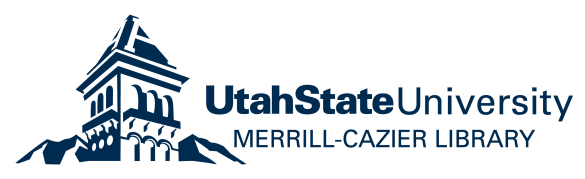




\section{THE NORTH AMERICAN BEES OF THE}

\section{GENUS NOMIA}

T. D. A. COCKERELL

Of the University of Colorado, Boulder

No. 1745.-From the Proceedings of the United States National Museum,

Vol. 38, pages 289-298

Published June 14, 1910

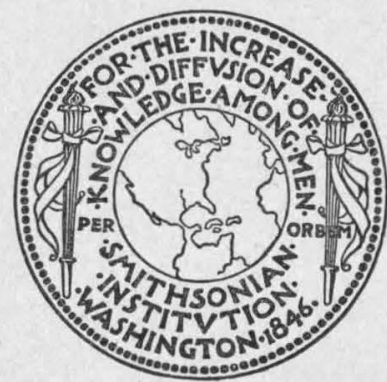

\section{Washington}

Government Printing Office 1910 


\section{THE NORTH AMERICAN BEES OF THE GENUS NOMIA}

BY

T. D. A. COCKERELL

Of the University of Colorado, Boulder

No. 1745.-From the Proceedings of the United States National Museum,

Vol. 38, pages 289-298

Published June 14, 1910

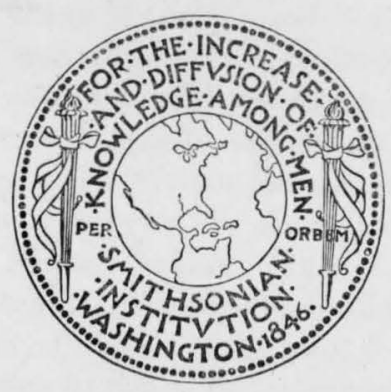

Washington

Government Printing Office 


\title{
THE NORTH AMERICAN BEES OF THE GENUS NOMIA.
}

\author{
By T. D. A. Cockerell, \\ of the University of Colorado, Boulder.
}

For many years past the National Museum has possessed a series of undescribed species of the genus Nomia, to which Dr. W. H. Ashmead gave manuscript names. In the new catalogue of bees now in preparation I was anxious to cite these names, but as their esteemed author unhappily never found time to prepare descriptions, I asked for the loan of the material in order to publish the necessary diagnoses. While giving these, I have thought it useful to arrange the species into groups and cite all those belonging to our fauna.

At the outset the question arises as to the number of genera to be recognized. Doctor Ashmead, in 1899, divided the Nomia of authors into Epinomia Ashmead, Nomia Latreille, Paranomia Friese, and Monia Westwood (Eunomia Cresson). Monia, however, is really a Colletid, and since Eunomia is preoccupied it takes the name Dieunomia Cockerell. ${ }^{a}$ Other segregates are the African Crocisaspidia Ashmead and Stictonomia Cameron, and the Asiatic Hoplonomia Ashmead (type H. quadrifasciata Ashmead).

The common usage in the United States has been to recognize two genera, Nomia and Eunomia (Dieunomia). It is not quite clear whether Nomia can be usefully split up into a number of genera, but at present it seems better to regard all the American forms as pertaining to a single genus with several named subgenera. The type of Nomia is the European N. diversipes Latreille, of which I have specimens from Doctor Friese. This is a strongly punctured insect, with very large tegulæ and curious laminate tubercles. It represents a subgeneric group (Nomia, s. str.) not found in America. N. ruficornis Spinola belongs to the same subgenus, which is also characterized by a backwardly-directed tooth at each side of the scutellum in the male. $N$. ruficornis has what at first sight seem to be white tegumentary bands on the abdomen, but they are really bands of dense

$a$ Entomologist, vol. 32 , p. 14.

Proceedings U. S. National Museum, Vol. 38-No. 1745.

Proc.N.M.vol.38-10-19 
white hair at the bases of the segments, more or less covered by the hyaline apices of the segments before.

Paranomia Friese (type, chalybeata Smith, from China) includes the species with colored pearly bands on the abdomen, represented in America by the group of $N$. nortoni. Hoplonomia Ashmead is similar, but has a bidentate process or two teeth on the postscutellum.

Epinomia Ashmead (type, triangutifera Vachal) should probably be extended to include the group of $N$. nevadensis. This is the most "normal" of our groups of Nomia, in the sense of being less divergent from other bees.

Dieunomia (type, marginipennis Cresson) consists of large species, in which the last antennal joint is broadened and flattened. N. bolliana, a smaller species just described, must also be referred here.

It would not be illogical to exclude Nomia from the American fauna, and recognize three genera, Paranomia, Epinomia, and Dieunomia; but in this case it would be necessary to decide what to do with the numerous African, Asiatic, and Australian species, which in various ways seem to connect the segregated genera with true Nomia, or in some cases form what might be regarded as other genera or subgenera. I have a considerable series of these foreign insects and am at a loss to know how to satisfactorily divide them into genera. The group is a peculiar one, and apparently its little morphological jokes must not be taken too seriously.

Perhaps the most significant distinctions are to be found in the mouth parts. In the type of the genus, Nomia diversipes, I find the tongue short, broad at the base, rapidly narrowing to a linear tip. The labial palpi have the first joint much shorter than the other three combined (proportions about 13 to 20), and the maxillary palpi extend beyond the maxillary blade, which is very bristly at the end. In Nomia nevadensis the conditions are essentially the same, but the first joint of the labial palpus is to the others combined as about 13 to 18 , the apical joint being shorter. In $N$. foxii the first joint of the labial palpus is to the other three combined as about 20 to 22, approaching equality, while the tongue is considerably elongated, gradually tapering, its length about $1,275 \mu$, its width at base about 220 , not counting the hair.

The following figures give the lengths of the joints of the labial palpi in microns. For the first joint only the dark chitinized part is measured.

\begin{tabular}{|c|c|c|c|c|}
\hline 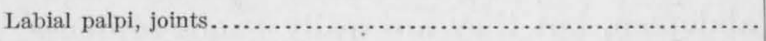 & (1) & $(2)$ & (3) & $(4)$ \\
\hline 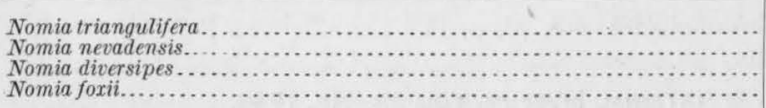 & $\begin{array}{l}510 \\
220 \\
220 \\
340\end{array}$ & $\begin{array}{l}220 \\
100 \\
100 \\
127\end{array}$ & $\begin{array}{l}204 \\
100 \\
110 \\
127\end{array}$ & $\begin{array}{l}220 \\
100 \\
136 \\
127\end{array}$ \\
\hline
\end{tabular}


In typical Epinomia (triangulifera) the tongue is short. In Dieunomia it is dagger-shaped. In Paranomia it is elongated. In Hoplonomia, which is really a section of Paranomia, it is long and slender, as I find on examining a specimen of $N$. elliottii Smith, from India. I also find a linear tongue in some Australian species, as $N$. semiaurea Cockerell and $N$. gilberti Cockerell, the latter having it remarkably long and slender.

The tongue and mouth parts of Nomia diversipes are typically Halictine in character, and compared with those of Agapostemon melliventris Cresson, they show no important difference. The large hyaline inner lobe of the maxillary blade is quite the same, and this is especially noteworthy because Andrena shows an entirely different structure, with no hyaline lobe. Nomia can not go in the Andreninæ, but must be considered to typify a subfamily Nomiinæ, closely related to the Halictinæ.

The following notes compare Hálictine with Nomiine bees:

Agapostemon melliventris Cresson. A specimen compared with Nomia diversipes showed a difference in the paraglossæ, which hardly exceeded the apex of second joint of labial palpi, while in $N$. diversipes they reached the level of base of last joint. The Agapostemon was a male, and on examining a female of the same species, it was found that the paraglossæ nearly reached the tip of the labial palpi. In Agapostemon radiatus Say the paraglossæ were found to reach about the level of the end of the labial palpi. The tongue and labial palpi are longer in this species than in $A$. melliventris.

Sphecodogastra texana (Cresson) has the tongue as in Nomia diversipes, and the broad paraglossæ reach the middle of the last joint of labial palpi. The maxillary palpi are much larger and longer than in N. diversipes.

Halictus sisymbrii Cockerell differs from Nomia diversipes by the much broader and shorter tongue, with the linear apical part very much shorter.

Halictus armaticeps Cresson has the tongue a little more slender than in Nomia diversipes, but it tapers much more gradually to the linear apical process, which is also shorter.

It is evident that the Halictines and Nomiines have independently produced groups with linear tongues. There are two such groups among the Halictines which I consider to have generic value, namely, Augochlora in America, and Thrinchostoma in Africa. It may be asked why, if I consider these valid genera, I do not also accept Paranomia as a genus on the same grounds. It is because I have never seen a species of Augochlora or Thrinchostoma, which could not be readily recognized as such, while I do not know how to divide Nomia into similarly recognizable groups. This, however, may 
merely be due to insufficient acquaintance with the numerous Asiatic and African species.

In connection with the evident relationship of the Nomiines to the Halictines, it is interesting to note that some of the latter have ivory-colored or yellowish tegumentary abdominal bands; such are Hatictus vittatus Smith from South Africa and H. flavovittatus W. F. Kirby from Socotra.

Nomia is doubtless of Old World origin, probably reaching America in later miocene times. Two species, $N$. jenseni Friese and $N$ jörgenseni Friese, have recently been described from Argentina, but Vachal points out that they have colletid mouth parts, and refers them to his genus Lonchopria. They are very beautiful insects, with light tegumentary abdominal bands in the manner of Paranomia, but the male antennæ are short, and neither the metathorax nor the venter of the abdomen are constructed as in Nomia.

\section{GROUP OF NOMIA NEVADENSIS.}

Rather small species, the abdomen without iridescent bands; male with the hind tibia broad, its inner edge with the apical half broadly excavated; tegulæ and tubercles not enlarged.

(A) Abdomen wholly or largely bright ferruginous.

Nomia nevadensis Cresson. Described from Nevada, and ranges through Arizona into New Mexico, where it is common in the middle Sonoran zone at flowers of various compositæ, as Bahia dissecta, Leucosyris spinosa and Isocoma wrightii.

(B) Abdomen dark.

Nomia bakeri Cockerell. Found in Colorado, at Denver and Boulder. Mrs. Bennett has collected it at flowers of Solidago.

\section{- NOMIa PATtONI, new species.}

Nomia pattoni Ashmead MS. (No description.)

Closely related to $N$. bakeri, but smaller (size of $N$. arizonensis), the female with the femora red, as well as the tibiæ and tarsi, the antennæ also red. In the male, the face is narrower below; the hind legs, though paler, do not differ in structure, and the male antennæ are practically the same in both. There are no tangible differences in sculpture. The length of the anterior wing is a rather scant $8 \mathrm{~mm}$. At first sight, $N$. pattoni looks like $N$. arizonensis, but it agrees with bakeri and differs from arizonesis in the character of the basal area of metathorax, which is rather large, and more or less boat-shaped, instead of narrowly crescentic. $\quad N$. pattoni is also readily known from arizonesis by the color of the legs, the more densely punctured mesothorax, and the absence of an evident subbasal constriction on the second abdominal segment of the female. It may perhaps prove to 
be a subspecies of $N . \%$ baeri, but in any event it will be easily distinguished in its typical range.

Habitat:-Utica, Mississippi (type-locality), from Ashmead's collection; Selma, Alabama, October, 1880, and July, 1881 (W. H. Patton, collector.)

Type-specimen.-Cat. No. 12984, U.S.N.M.

A female from Selma, Alabama, is labeled "Sept. 30, 1880. E. A. Schwarz. See notes on Myodites."

Named for W. H. Patton.

NOMIA ARIZONENSIS Cockerell.

The U. S. National Museum has a long series from Arizona, the precise locality, whenever given, being Tucson. In the male the wings, except for the broad dark apical border, are very pale, almost milky; but in the females they are more yellowish or dusky. The females have collected a great quantity of orange pollen, no doubt from the compositæ. In the male, the median depression or constriction of the first three abdominal segments is extremely marked, and the flagellum is ferruginous beneath, this color abruptly contrasting with the black which occupies two-thirds of the circumference.

NOMIA ARIZONENSIS ANGELESIA, new subspecies.

Nomia angelesia Ashmead MS. (No description.)

I was first inclined to treat this as identical with $N$. arizonensis, but it is normally larger (anterior wing, $8 \frac{3}{5} \mathrm{~mm}$.). The mesothorax seems less densely punctured, and the male flagellum is quite differently colored, being very dark reddish beneath, the red shading into the black. The basal area of the metathorax is very narrow (i. e., short antero posteriorly). The tegulæ are clear fulvotestaceous, and the light abdominal hair-bands are very distinct.

Habitat.-Los Angeles County, California (D. W. Coquillett) - typelocality; San Bernardino County, California, "338, through C. V. Riley."

Type-specimen.-Cat. No. 12985, U.S.N.M.

\section{GROUP OF NOMIA TRIANGUIIFERA (EPINOMIA).}

Larger than the species of the nevadenis group; abdomen black, without iridescent bands; hind tibiæ of male much broadened apically, produced at the inner apical corner into a large stout spine, but the inner side only slightly concave beyond the middle, not excavated. The triangular depression on the fourth ventral segment of the male is also well marked in the nevadensis group, becoming narrower, however, in $N$. arizonensis angelesia. The females resemble species of Andrena, and may be found visiting species of Compositæ. 
The apical joint of the male antennæ is not dilated in the triangulifera or nevadensis group. The inclosure of the metathorax in N. triangulifera is boat-shaped, more or less narrowed in the middle. The tegulæ in the female are variably infuscated, whereas in all members of the nevadensis group they are pellucid rufotestaceous.

The only species of this group is Nomia triangulifera Vachal, 1897 (persimitis Cockerell 1898), found in Nebraska, Kansas, and New Mexico. It is the type of Ashmead's genus Epinomia.

\section{GROUP OF NOMIA HETEROPODA (DIEUNOMIA).}

Very large species; abdomen black, without iridescent bands; males with apical joint of antennæ swollen, and middle femora greatly swollen, the hind legs also much modified, the hind basitarsus extremely long.

(A) Wings uniformly dark fuliginous.

Nomia heteropoda Say. A female from Victoria, Texas, at flowers of Hetianthus, October 2, 1904 (J. C. Crawford, collector), is referred here.

(B) Wings hyaline, orange-tinted, with the apical margin very broadly fuliginous.

Nomia apacha Cresson. I refer here two females from Victoria, Texas, at flowers of Hetianthus, October 2, 1904 (A. J. Leister, collector). I am at some disadvantage with regard to this and the last species from having only females (the male of apacha is unknown), and from not having authentic material for comparison; I have seen the species, however, in the Cresson collection, and the present specimens accord very well with my notes and recollections. The apacha and heteropoda were taken at the same place, on the same day, at Helianthus, and appear to be identical except for the very different coloration of the wings. Is it possible that they are two forms of a single species?

N. apacha is known to be western (Colorado, New Mexico), while $N$. heteropoda is eastern (Texas to Arkansas and Maryland); do they meet at Victoria, Texas, and possibly hybridize? There is apparently a problem here calling for field investigations.

From the other species with similarly colored wings, N. apacha is readily known by the combination of strongly fulvous pubescence on the thorax above with light fulvous tegulæ and a very black, unbanded, abdomen.

N. marginipennis Cresson. Afemale before me is from Rocky Ford, Colorado, collected by Prof. C. P. Gillette.

Nomia xerophila Cockerell. Mesilla Park and Aztec, New Mexico; Sterling, Colorado (S. A. Johnson, collector); Moab Utah, "S. 10,'06" (U.S. National Museum). In the male, it is the fourth ventral segment which is elevated at the lower lateral corners, and the fifth which 
bears nodules, not the third and fourth, respectively, as stated in the original description. $^{a}$ In this species the hair of the thorax above is pale yellowish-gray, unlike the fulvous of apacha or the seal-brown of marginipennis; the tegulæ are darker than in apacha, but not so dark as in marginipennis.

\section{GROUP OF NOMIA MESILLA.}

Known only from a single male, the type of $N$. mesillæ (Cockerell). It is similar in most respects to the males of the heteropoda group, but the middle femora are less modified, the middle tibix have no spurs, and there are other differences. The abdominal hair-bands are very distinct. The insect was taken by Mr. C. M. Barber at Mesilla, New Mexico.

\section{GROUP OF NOMIA BOLLIANA.}

The only species known is N. bolliana Cockerell, 1910, from Texas. The female looks at first sight just like $N$. triangulifera, agreeing in size, build, color, and manner of collecting pollen. Upon close comparison many differences are apparent, such as the narrowly crescentic area of metathorax, the more sparsely punctured first abdominal segment, and the pellucid rufo-fulvous tegulæ, which are quite elongate, sinuate on the outer margin, in the manner of the heteropoda group. The tibiæ and tarsi are ferruginous. The wings are colored as in $N$. apacha. The male is very different from that of $N$. triangulifera, the following characters being distinctive: Antennæ long, black, the flagellum crenulated, with the apical joint flattened and broadened, as in the heteropoda group; face broad, densely covered with yellowish-white hair; tongue narrow apically, broadened basally, very hairy; vertex and thorax above with very pale yellowish hair, colored as in $N$. xerophila; area of metathorax strongly plicate; abdomen densely punctured, first three segments constricted; fourth ventral segment with median depression parallel-sided, not at all triangular (but it may broaden under the margin of third), and its lateral angles not elevated; fifth ventral with a pair of nodules; femora black, except knees, tibiæ and tarsi ; ferruginous; middle femora very little swollen, inclined to be keeled beneath; middle tibiæ and tarsi ordinary, the tibial spur present; hind trochanters produced to a large obtuse tooth, and with a little basal process on outer side; hind femora much swollen, very convex above; hind tibiæ broadly triangular, the lamina produced to a prominent submedian angle, and with also an apical process; hind basitarsus not excessively long.

This species was described from a single female in the Berlin Museum. The U. S. National Museum contains both sexes, from 
Denton and Wichita Falls, Texas. The Wichita Falls (female) specimen is from flowers of Helianthus, June 10, 1906 (J. D. Mitchell, collector). The Denton (both sexes) specimens are from flowers of Rudbeckia amplexicaulis, June 29 (F. C. Bishopp, collector).

The produced hind trochanters of the male occur also in all members of the nevadensis group.

\section{GROUP OF NOMIA NORTONI. (PARANOMIA.)}

Hind margins of abdominal segments iridescent green or blue; tongue slender; apex of male antennæ neither flattened nor dilated.

(A) Male antennæ long, with the last joint elongated and sharply pointed.

Nomia nortoni Cresson. Kansas, Texas, and New Mexico. $N$. cressoni Westwood, from Mexico, is the same. I have a Mexican specimen. This species is much the largest of the group; anterior wing about $13 \mathrm{~mm}$.

N. melanderi Cockerell. Known only by a single female from Washington State. It is not certain, in the absence of the male, that this belongs in the subgroup with pointed antennæ, but I believe it is correctly so referred.

NOMIA CALIFORNICA, new species.

Nomia californica Ashmead MS. (No description.)

Female.-Size and form of $N$. melanderi, from which it differs as follows: Abdominal bands light yellowish-green, with a variable amount of orange suffusion; first segment with an entire narrow apical band; stigma redder. Thus, while the differences are technically very slight, the insect looks quite distinct. There is a good deal of short black hair on the thorax above, and the tegulæ are reddish black.

Habitat.-Southern California, "No. 331, through C. V. Riley;" Los Angeles County, California (D. W. Coquillett, collector).

Type-specimen.-Cat. No. 12986, U.S.N.M.

NOMIA ACUS, new species.

Male.-Anterior wirg a fraction over $9 \mathrm{~mm}$. Male flagellum long, pale yellowish-fulvous beneath, the last joint long and pointed as in $N$. nortoni; thorax above very strongly punctured, and with grayishwhite hair, scutellum slightly bigibbous; abdomen narrow basally, the first two segments very coarsely punctured, the others finely; first segment with hind margin wholly dark; segments 2 to 5 with broad light bluish-green bands; structure of legs as in N. nortoni, the hind femora greatly swollen, and the hind tibiæ with a very large quadrangular pale honey-colored lobe; tarsi fuscous; fourth ventral abdominal segment divided into two plates as in N. nortoni. This 
is at once distinguished from $N$. melanderi and californica by the strong relatively much denser puncturation of disk of mesothorax, scutellum, and first abdominal segment; but in Nomia this may be only a sexual character. In the color of the bands this agrees with N. melanderi, but the tegulæ are hyaline with a fulvous spot, whereas in melanderi they are opaque black. From the locality, one would associate it with $N$. californica, but the color of the bands is quite different, and the first segment has no light band. The wings are yellower than in melanderi or californica, and the apical margin is paler. The face is rather narrow, and the orbits converge below. The clypeus is shining and somewhat concave.

Habitat.-Southern California, "through C. V. Riley."

Type-specimen.-Cat. No. 12987, U.S.N.M.

(B) Male antennæ elongate, slender apically, but the point obtuse. Species of the West Indies.

Nomia robinsoni Cresson. Cuba.

N. wickhamii Ashmead. Eleuthera, Bahamas. The type is before me, collected by Henry Ditzen. It is evidently very close to $N$. robinsoni, but easily distinguished by the much greater amount of black on the tibiæ. From Ashmead's description, I had difficulty in separating this from $N$. foxii, but it is really quite distinct, differing as follows: Hair of face yellowish; scape much larger and thicker; flagellum much longer, more slender apically; mesothorax and first abdominal segment more closely punctured; dorsum of thorax appearing very black, fringed with pale yellowish hair; abdominal bands paler, with turquoise tints; yellow lobe of hind tibia larger.

(C) Male antennæ ordinary; first abdominal segment with no green or blue band.

Nomia foxii Dalla Torre. New Mexico.

N. mesillensis Cockerell. New Mexico. Only the female is known, but I believe it falls in this group.

N. universitatis Cockerell. Colorado.

NOMIA TETRAZONATA, new species.

Nomia tetrazonata AsHMEAD MS. (No description.)

Male.-Length about or hardly $10 \mathrm{~mm}$., anterior wing $7 \frac{1}{3}$; the four abdominal bands rather narrow, light turquoise blue, with slight green tints. Very close to N. foxii and universitatis, but uniformly smaller. Compared with $N$. foxii it is readily distinguished by the sculpture of the abdomen. In foxii the third segment has rather small, irregularly placed punctures of different sizes, while the fourth has very small punctures. In tetrazonata the fourth has large regular punctures like those on the third, while those on the fifth could not be called minute. The second segment is depressed basally. The hind femora are considerably stouter than in N. universitatis; the hind tibiæ are unusually 
short, and seen from behind both they and their tarsi are of a uniform brown, hoary with fine pubescence; seen from in front, the apex of the tibial lobe is broadly yellowish-white; the anterior and middle tarsi are also brown. The punctures of the mesothorax are smaller than in foxii or universitatis. The face is covered with white hair, and the flagellum is dull ferruginous beneath. The tegulæ are as in foxii.

Habitat.-Globe, Arizona, July 25, 1892, three from Ashmead's collection; also one from "Bradsh. Mt.," June 21, 1892, also in Arizona, and from Ashmead's collection. Type from Globe, with number 147 .

Type-specimen.-Cat. No. 12988, U.S.N.M.

\section{DOUBTFUL AND EXCLUDED SPECIES.}

Andrena valida Say. Viereck (in litt.) •has suggested that this may be a Nomia. If so, it must be closely similar to $N$. heteropoda, being a large species with purplish-fuliginous wings.

Nomia birkmani Friese MS., Entom. News, 1899, p. 244, from Texas, has not been described.

N. compacta Provancher, 1888, from Cap Rouge, Canada, is based on a male, and from the locality and description I suspect that it may not be a Nomia. The following characters seem significant: "La face allongée, presque nue, le chaperon noir foncé, fortement tronqué en avant et légèrement réfléchi, brillant . . . pattes noires, brillantes, les cuisses et les jambes renflées, arquées, avec poils blancs peu denses, les tarses testacés-roussâtres . . le septième [segment of abdomen] portant un petit appendice noir en forme de gouttière."

Paranomia venablesii Ashmead belongs to Halictus (H. farinosus Smith).

Nomia tacita Cameron is Agapostemon sicheli Vachal.

Nomia cillaba Cameron is also an Agapostemon.

Nomia cælestina Westwood is an Agapostemon. 
1 